\title{
Right without Remedy? The development of the presumption of innocence at the International Criminal Court
}

\section{Introduction}

The year 2022 marks the twentieth anniversary of the Rome Statute's entry into force. During these years some of the ideas encapsulated in the Rome Statute have changed and developed in ways not contemplated by the drafters. One such example is the presumption of innocence. In writing the Rome Statute of the International Criminal Court, the drafters considered defence rights of the utmost importance. The travaux préparatoires indicate that the presumption of innocence was important, and its inclusion was never in doubt, however there is very limited discussion of what the presumption of innocence consists of, how it is violated, or what remedy should be available in cases of violation. Despite this lack of specificity in the drafting documents, over the last twenty years the Court itself has interpreted the presumption of innocence to be more expansive, specific, and in line with international standards.

Article 66 of the Rome Statute provides for the right to the presumption of innocence before the International Criminal Court. This article specifically provides that everyone shall be presumed innocent until proven guilty, that the onus to prove guilt is on the Prosecutor, and that the standard of proof for a guilty verdict is beyond reasonable doubt. However, several other issues, such as how this right should be protected, at what stages in the proceedings it applies, and what would happen in the event of a violation, have all been open to wide interpretation by the Court. This 
interpretation has allowed the presumption of innocence to include both a procedural and nonprocedural aspect which means that it has application both within and beyond the trial context. Despite this development, no violation has been found by the International Criminal Court, and thus what remedy might be appropriate for any potential violation has also not been determined.

This paper examines the development of the presumption of innocence at the International Criminal Court. While the presumption of innocence was hardly discussed at the Rome Conference, this paper argues that since the Rome Statute's entry into force, the presumption of innocence has gone from the text of Article 66 to a rather robust right that helps guarantee that the burden and standard of proof are upheld, ensures that suspects and accused persons have a fair trial, and protects people who have not been convicted of a crime from receiving the same treatment as convicted people. It further explores the development of when the rights contained in Article 66 apply. The Court has held that the presumption of innocence has application both inside and outside of the courtroom and has effect during the Situation, PreTrial and Trial phases. Despite these developments, what happens when the right is violated remains an open question. The paper will conclude that while the presumption of innocence may be better defined and more protective than it was twenty years ago, what happens in the case of a violation remains an area for further development.

\section{The Presumption of Innocence Generally}


The presumption of innocence is a human right universally contained in national, international, and regional criminal justice systems. ${ }^{1}$ It is a fundamental right to which all people who are suspected or accused of crimes can benefit and it has deep roots in the structure of criminal justice systems and the rule of law. ${ }^{2}$ This section of the paper will look at what the presumption of innocence is as a human right. Examining what constitutes the presumption of innocence in mature legal systems can help in the evaluation of how the right has developed through the foundation and first cases at the International Criminal Court.

The presumption of innocence contains two aspects: the procedural and non-procedural. ${ }^{3}$ The procedural aspect is the part of the presumption of innocence of which most people are familiar. It is a mandatory rebuttable presumption of law which requires the factfinder to find the accused person not guilty unless certain criteria are met. The first is that the burden of proving guilt must be on someone other than the accused person. ${ }^{4}$ The second is that the proof of guilt must rise to

\footnotetext{
${ }^{1}$ M Cherif Bassiouni, 'Human Rights in the Context of Criminal Justice: Identifying International Procedural Protections and Equivalent Protections in National Constitutions' 3 Duke J. Comp. \& Int. Law (1993) 235-236. International Covenant on Civil and Political Rights art 14(2); European Convention on Human Rights art 6(2); American Convention on Human Rights art 8(2); African Charter on Human and People's Rights (published on 27 June 1981, entry into force 21 August 1986) 1520 UNTS 217 art 7(1)(b); ICC Statute art 66.

${ }^{2}$ Andrew Stumer, The Presumption of Innocence (Hart, Oxford, 2010) p. 3; Matthew Hale, Historia Placitorum Coronae (1736) pp. 289, 290; François Quintard-Morénas, 'The Presumption of Innocence in the French and AngloAmerican Traditions' 58(1) American J. Comp. Law (2010) 116.

${ }^{3}$ For a comprehensive analysis of the presumption of innocence see, Michelle Coleman, The Presumption of Innocence in International Human Rights and Criminal Law (Routledge, London, 2021).

${ }^{4}$ Haji NA Noor Muhammad, 'Due Process in Law for Persons Accused of Crime' in Louis Henkin (ed), The International Bill of Rights: The Covenant on Civil and Political Rights (Columbia University Press, New York, 1981) p. 150; Liz Campbell, 'Criminal Labels, the European Convention on Human Rights and the Presumption of Innocence’ 76(4) Mod. Law Rev. (2013) 683, DOI: 10.1111/1468-2230.12030; Yvonne McDermott, Fairness in International Criminal Trials (Oxford University Press, Oxford, 2016) p. 44; John D Jackson and Sarah J Summers, The Internationalisation of Criminal Evidence (Cambridge University Press, Cambridge, 2012) p. 201; Statute of the Special Tribunal for Lebanon Art. 16(3); ICC Statute art 66; ICTY Statute art 21(3); ICTR Statute art 20(3); SCSL Statute art 17(3); European Convention on Human Rights art 6(2); American Convention on Human Rights art 8(2); Internal Rules, Extraordinary Chambers in the Courts of Cambodia, Internal Rules (Rev. 7) as revised on 23 February 2011, rule 87(1); United Nations General Assembly, Universal Declaration of Human Rights (GA Res 217 A (iii) UN Doc A/8810) art 11(1); American Declaration of the Rights and Duties of Man, OAS Doc. OEA/SER.L./V/I.4 (1948) art XXVI; ICCPR art 14(2); African Charter on Human and People's Rights (published on 27 June 1981, entry into force 21 August 1986) 1520 UNTS 217, art 7(1)(b).
} 
that jurisdiction's standard of proof, which includes, but is not limited to, adherence to the in dubio pro reo principle. ${ }^{5}$ If either of these criteria are not met, then the factfinder must find the accused not guilty because the legal presumption has not been overcome. It is only if both of these criteria are met that the factfinder can find the accused guilty of the crimes of which they are charged.

The second part of the presumption of innocence is the non-procedural aspect. The non-procedural aspect goes beyond the instruction to the factfinder to determine how a non-convicted person may be treated. It includes how an accused person may be presented in public, the rules governing predetermination detention, and what public officials may say publicly about a non-convicted person. ${ }^{6}$ This aspect is not a specific instruction, but instead is more qualitative in nature and can include protection against any kind of treatment toward a non-convicted person which states or implies that they are guilty of a crime.

Both the procedural and non-procedural aspects of the presumption of innocence must be upheld for the presumption of innocence to be a functional human right that provides protection for people within the criminal justice system. If any part of the presumption of innocence is violated, then it stands that a remedy should be provided for that violation. That remedy should restore the presumption of innocence and ensure that the fair trial rights are protected for the non-convicted

\footnotetext{
${ }^{5}$ Hock Lai Ho, 'The Presumption of Innocence as a Human Right' in Paul Roberts and Jill Hunter (eds.), Criminal Evidence and Human Rights, (Hart, Oxford, 2012) pp. 267-8; McDermott, supra note 4, p. 44; International Law Commission, Yearbook of the International Law Commission 1993, vol II, part 2 (1994) UN Doc No A/CN.4/SER.A/1994/Add.1 (Part 2) 119; ICTY, Prosecutor v. Mucić et al., IT-96-21-T, Trial Chamber, Judgement, 16 November 1998, para. 600.

${ }^{6}$ Human Rights Committee, 'General Comment No. 32: Right of Equality Before Courts and Tribunals and to Fair Trial' (23 August 2007) UN Doc No CCPR/C/GC/32 (2007) (General Comment 32) para 39; W. Schabas and Y. McDermott, 'Article 66: Presumption of Innocence' in Otto Triffterer and Kai Ambos (eds.), Rome Statute of the International Criminal Court: A Commentary (3rd edn, CH Beck 2016) p. 1648, para 32.
} 
person. The possible remedy determined for violations of the presumption of innocence depend on what reason the presumption of innocence exists.

The purpose of the presumption of innocence is to prevent people who have not been convicted from being treated in the same manner as those who have been convicted. Courts and scholars claim several purposes of the presumption of innocence including to: prevent people who have not been convicted from being treated the same as those who have been convicted of a crime; prevent tainting or bias on the part of the factfinder; force the standard and burden of proof on someone other than the accused (usually the prosecutor); promote the legitimacy of the court and/or criminal justice system; and uphold the rule of law. ${ }^{7}$ The first three purposes all go to protecting the rights of the accused, while the other two are broader rights that go to structural issues. However, the purpose of protecting people who have not been convicted of a crime from being treated in the same manner as those who have been convicted is the only purpose which covers all the others. ${ }^{8}$ This purpose is most in line with both the historical and modern uses of the presumption of innocence. It also maintains the presumption of innocence as a human right and at the same time puts a check on the power that the government can exert over individuals and supports the criminal justice system and rule of law.

In general, jurisdictions may have varying degrees of adherence to the two parts of the presumption of innocence. However, in order to be fully compliant with the right, the jurisdiction must provide

\footnotetext{
${ }^{7}$ For some examples of this debate see Andrew Ashworth 'Four Threats to the Presumption of Innocence' 123(1) S. African Law J. (2006) pp. 73-4; Thomas Weigend, 'There is Only One Presumption of Innocence' 42(3) Netherlands J. Legal Phil. (2013) 193, DOI: 10.5553/NJLP/221307132013042003003; Ho, supra note 5; Magnus Ulväng, 'Presumption of Innocence Versus a Principle of Fairness' 42(3) Netherlands J. Legal Phil. (2013) 205, DOI: 10.5553/NJLP/221307132013042003004; Antony Duff, 'Presumptions Broad and Narrow' 42(3) Netherlands J. Legal Phil. (2013) 268, DOI: 10.5553/NJLP/221307132013042003008.

${ }^{8}$ Coleman, supra note 3 , pp. 25-32.
} 
all the protections within both aspects. At the International Criminal Court, as will be discussed below, the Court was initially very concerned about the procedural aspect while the non-procedural aspect has developed more slowly over time. At this point both aspects are fairly well developed in line with international human rights standards. However, questions remain as to where the limits to the right lie, what it would take to violate the presumption of innocence at the International Criminal Court, and what remedy would be permitted to address a violation.

\section{The Travaux Préparatoires}

The Rome Statute negotiations are surprisingly quiet about the nature of the presumption of innocence and what form it would take at the International Criminal Court. Overall, the discussions were limited and had very little to do with the actual content of what would become Article 66. The main argument regarding the presumption of innocence was where it would be housed in the Statute. That is, whether it should be in the section titled 'General Principles of Law' or 'The Trial'. The 1996 Preparatory Committee draft had it within both sections while in the later Zutphen Draft the presumption of innocence was only contained within 'General Principles of Law'. ${ }^{9}$ In the final version the presumption of innocence is under 'The Trial' ${ }^{10}$ This discussion amongst the drafters shows that the presumption of innocence was an important right to be included within the Statute and although in the end it is contained in 'The Trial', the debate of whether it should be included in General Principles of Law demonstrates that the presumption may have application

\footnotetext{
${ }_{9}^{9}$ Schabas and McDermott, supra note 6, p. 1639 para 11.

${ }^{10}$ Article 66 of the Rome Statute.
} 
beyond the actual trial itself. This idea is further supported by the fact that Article 66 stands alone, separate from the other rights of the accused.

The other significant change that occurred within the travaux préparatoires, was a change in the wording regarding who can claim the right to the presumption of innocence. Earlier drafts show that the right was limited to 'the accused' however, it is provided to 'everyone' in the final version. ${ }^{11}$ This is expansive wording that indicates that the right is not limited to those who are officially charged and further supports the idea that the presumption of innocence may have application beyond the trial itself.

While it was clear that the inclusion of the presumption of innocence was important to the drafters, they were not very concerned with the details of what the right to the presumption of innocence would include. They knew it would apply during the trial, but it might be a general principle of law. They also knew that they wanted the presumption of innocence to be very inclusive, hence using the word 'everyone' rather than limiting the right to particular groups within the criminal process such as suspects or the accused. Further, as the discussion of Article 66 below will expand upon, the drafters set out a fairly clear and solid right as far as the procedural aspect was concerned. While the procedural aspect has had some development, it is the non-procedural aspect that has undergone the most change through the Court's jurisprudence.

\section{The Procedural Aspect of the Presumption of Innocence}

\footnotetext{
${ }^{11}$ Schabas and McDermott, supra note 6, p. 1639, para. 11; 1996 Preparatory Committee II, see note 14, p 194.
} 
The result of the negotiation process is Article 66 which is housed in the 'The Trial' Section of the Rome Statute. Article 66 provides:

1. Everyone shall be presumed innocent until proved guilty before the Court in accordance with the applicable law.

2. The onus is on the Prosecutor to prove the guilt of the accused.

3. In order to convict the accused, the Court must be convinced of the guilt of the accused beyond reasonable doubt. ${ }^{12}$

This article clearly states the procedural aspect of the presumption of innocence as it is understood at the International Criminal Court. It instructs the factfinder to find the accused not guilty unless and until the burden and standard of proof have been met, allocates the burden of proof on the Prosecutor, and sets the standard of proof. It should be no surprise that the procedural aspect has been fairly strictly construed at the court. For example, the burden of proof never shifts away from the Prosecutor, which means, among other things, that the victims cannot contribute to meeting the standard of proof when they participate in proceedings. ${ }^{13}$ Also there is a right to silence which has developed out of the presumption of innocence, which means that the accused is not obliged to testify on their own behalf and that inferences cannot be drawn from their silence. ${ }^{14}$ These examples support the idea that the burden of proof never shifts to the accused at the International

\footnotetext{
${ }^{12}$ Article 66 of the Rome Statute.

${ }^{13}$ ICC, The Prosecutor v. Thomas Lubanga Dyilo, ICC-01/04-01/06, Appeals Chamber, International Criminal Court, Judgment on the Appeals of the Prosecutor and The Defence Against Trial Chamber I's Decision on victims' Participation of 18 January 2008, 11 January 2008, para. 97. Michelle Coleman, 'The Tension between the Presumption of Innocence and Victims' Participation Rights at the International Criminal Court' 20 Int. Crim. Law Rev. (2020) 371-393, DOI: 10.1163/15718123-01906004.

${ }^{14}$ ICC Statute art 55(2)(b) and art 67(1)(g).
} 
Criminal Court and shows a dedication to a strict interpretation of the procedural aspect of the presumption of innocence.

Perhaps the most interesting development to come out of the interpretation of the presumption of innocence before the International Criminal Court is the creation of 'no case to answer' motions. These motions are not provided for in the Rome Statute or Rules of Procedure and Evidence, but were imported from the practice of the International Criminal Tribunal from the former Yugoslavia during the Ruto and Sang case. ${ }^{15}$ The defence can make this motion at the end of the prosecution's case, arguing that the prosecutor has not met the standard of proof for the crimes charged. ${ }^{16}$ If the motion is successful, as it was in Ruto and Sang, then the charges are vacated. If the motion is not successful, then the trial moves on to the defence's case as it normally would. The creation of the No Case to Answer Motion demonstrates a serious commitment on the part of the Court to the procedural aspect of the presumption of innocence. This type of motion upholds the idea that the burden of proof is solely on the prosecutor and the idea that the standard of proof must be met. Additionally, the potential outcomes of the motion support the notion that the Court must find the accused not guilty unless the burden and standard of proof are satisfied. The development of this motion is an example of how the Court itself has gone beyond the literal words of the Rome Statute

\footnotetext{
${ }^{15}$ ICC, Prosecutor v. Ruto et al., ICC-01/09-01/11, Trial Chamber V(A), Decision No. 5 on the Conduct of Trial Proceedings (Principles and Procedure on 'No Case to Answer' Motions), 3 June 2014; ICC, Prosecutor v. Ruto et al., ICC-01/09-01/11, Trial Chamber V(A), Public Redacted Version of Decision on Defence Applications for Judgments of Acquittal, 5 April 2016. This kind of motion was raised at the International Tribunal for the former Yugoslavia in ICTY, Prosecutor v. Mucić et al., IT-96-21-T, Trial Chamber, Order on the Motions to Dismiss the Indictment at the Close of the Prosecutor's Case, 18 March 1998. The motion in both of these cases was rejected, but it resulted in Rule 98bis.

${ }^{16}$ ICC, Prosecutor v. Ruto et al., ICC-01/09-01/11, Trial Chamber V(A), Decision No. 5 on the Conduct of Trial Proceedings (Principles and Procedure on 'No Case to Answer' Motions), 3 June 2014; ICC, Prosecutor v. Ruto et al., ICC-01/09-01/11, Trial Chamber V(A), Public Redacted Version of Decision on Defence Applications for Judgments of Acquittal, 5 April 2016.
} 
and Rules of Procedure and Evidence and interpreted the procedural aspect of the presumption of innocence to be in line with international standards.

While Article 66 has been interpreted in a fairly straightforward manner regarding the procedural aspect of the presumption of innocence, the Court has developed it further than what is strictly required by the text of the article. The burden of proof is strengthened by finding that victims cannot contribute to the burden and by reading in a right to silence which prevents the accused from being forced to provide evidence of their own guilt. Further, the creation of No Case to Answer Motions highlights how the burden and standard of proof must be met before the Court will find an accused person guilty.

\section{The Non-Procedural Aspect of the Presumption of Innocence}

The non-procedural aspect is the aspect that allows the presumption of innocence to have some reach outside the context of trial. While this aspect is not contained within the specific text of Article 66 or the Rules of Procedure and Evidence, the drafting history and the fact that Article 66 is separate from Article 67, which houses all defence rights specific to trial, are indications that the presumption of innocence may have reach beyond trial itself. Additionally, the non-procedural aspect has been recognized as a part of the presumption of innocence and significantly developed at the International Criminal Court through the case law. ${ }^{17}$ Unlike the procedural aspect, the nonprocedural aspect is not a specific instruction or particularly clear-cut. Rather, the non-procedural

\footnotetext{
${ }^{17}$ ICC, Prosecutor v. Gaddafi, ICC-01/11-01/11, Appeals Chamber, Decision on the Request for Disqualification of
} the Prosecutor, 12 June 2012, paras. 24-26. 
aspect of the presumption of innocence prevents non-convicted people from receiving the same treatment as that reserved for convicted persons. This includes both not punishing people who have not been convicted of a crime as well as not causing others to believe they have been convicted of a crime when they have not. ${ }^{18}$ As a result, this aspect can apply in a wide variety of circumstances and can change over time.

One example of the presumption of innocence extending beyond the context of trial is with regard to the in dubio pro reo principle. The International Criminal Court has held that this principle extends beyond the specific context of trial and applies at all stages of the Court's proceedings. ${ }^{19}$ This is important because it means that the judges in the investigation and pre-trial phases must also approach the accused and proceedings with the idea that the accused has not been convicted in mind. While in dubio pro reo does make up part of the procedural aspect of the presumption of innocence, applying it during the pre-trial phase prevents the factfinder from taking shortcuts to guilt or to treating non-convicted people as if they have been convicted of a crime.

The non-procedural presumption of innocence has also been read into the jurisprudence of the International Criminal Court by forbidding public statements of guilt from being made about people who have not been convicted of a crime. This was recognized and discussed in the

\footnotetext{
${ }^{18}$ Stefan Trechsel, 'The Right to be Presumed Innocent', in Stefan Trechsel and Sarah Summers (eds.), Human Rights in Criminal Proceedings (Oxford University Press, Oxford, 2006).

${ }^{19}$ ICC, Prosecutor v. Bemba, ICC-01/05-01/08, Pre-Trial Chamber II, Decision Pursuant to Article 61(7)(a) and (b) of the Rome Statute on the Charges of the Prosecutor Against Jean-Pierre Bemba Gombo, 15 June 2009, para. 31; Dov Jacobs, 'Standard of Proof and Burden of Proof', in Göran Sluiter, Håkan Friman, Suzannah Linton, Sergey Vasiliev, and Salvatore Zappalá (eds.), International Criminal Procedure: Principles and Rules (Oxford University Press, Oxford, 2013) p. 1137; Schabas and McDermott, supra note 6, p. 1006.
} 
Mbarushimana case. ${ }^{20}$ The International Criminal Court used the European Court of Human Rights case law to aid in developing this concept when deciding that statements by public authorities must not 'encourage the public to believe the suspect is guilty and prejudge the assessment of the facts by the competent judicial authority'. ${ }^{21}$ While what constitutes a 'public authority' may be construed broadly, for a public statement to violate the presumption of innocence it must be expressly linked to charges against the accused. ${ }^{22}$ The prohibition of public statements of guilt about those who have not been convicted of a crime is an important requirement for the non-procedural aspect of the presumption of innocence at the International Criminal Court because incidents that lead to charges at the Court are often well documented within the international community. While it may be known that something happened to cause suffering by a group of people, it is important to not create the impression that either that what caused that suffering is a crime and/or that who specifically is responsible for that suffering is already known. To allow public statements of guilt to be permitted for incidents before the International Criminal Court would give the impression that the verdicts are already set and that the trial process is a sham.

A related extension of the presumption of innocence beyond the courtroom is the prevention of too much negative publicity. Too much negative publicity within the media taint the reputation of the individual in the mind of the public and the factfinder. This may mean that they are prejudged as guilty or that it appears that they have been determined to be guilty before the criminal process

\footnotetext{
${ }^{20}$ ICC, Prosecutor v. Mbarushimana, ICC-01/04-01/10-51, Pre-Trial Chamber I, Decisions on Defence Request for an Order to Preserve the Impartiality of the Proceedings, 31 January 2011; ICC, Prosecutor v. Gaddafi, ICC-01/1101/11, Appeals Chamber, Decision on the Request for Disqualification of the Prosecutor, 12 June 2012.

${ }^{21}$ ECHR, $X$ v. Netherlands, 27 DR 37, 1981; ICC, Prosecutor v. Mbarushimana, ICC-01/04-01/10-51, Pre-Trial Chamber I, Decisions on Defence Request for an Order to Preserve the Impartiality of the Proceedings, 31 January 201, para. 161.

${ }^{22}$ Prosecutor v. Mbarushimana, ICC-01/04-01/10-51, Pre-Trial Chamber I, Decisions on Defence Request for an Order to Preserve the Impartiality of the Proceedings, 31 January 2011.
} 
is complete. Pre-Trial Chamber II identified this part of the non-procedural presumption of innocence in the Kenya Situation where it determined that the Prosecutor's Office should generally withhold the names of suspects during the Situation Phase, as this might expose the suspect to too much negative media attention. ${ }^{23}$ This is particularly important because several suspects may be identified during the Situation Phase but never formally charged at the Court. The negative publicity received because their names were released would unnecessarily cause these people who were never even charged with a crime to be stigmatised within the local and international communities.

Finally, the International Criminal Court recognises the presumption of innocence is an important consideration in deciding whether accused persons should be held in pre-determination detention. The International Criminal Court is somewhat unique in that it does not require accused persons to be housed in pre-determination detention while awaiting trial. ${ }^{24}$ This is permitted through Article 60(2) and Article 58(1) of the Rome Statute which require that accused persons must be released pending trial unless detention is necessary to ensure their presence at trial, to prevent their interference with the investigation, or to stop them from continuing to commit crimes within the Court's jurisdiction. ${ }^{25}$ This demonstrates a shift in attitude from earlier international and internatioanlised tribunals which either required the suspect's detention or only permitted the

${ }^{23}$ McDermott, supra note 4, p. 42; ICC, Situation in Kenya, ICC-01/09, Pre-Trial Chamber II, Decision on the "Application for Leave to Participate in the Proceedings before the Pre-Trial Chamber relating to the Prosecutor's Application under Article 58(7)", 11 February 2011, para. 22.

${ }^{24}$ The International Tribunal for the former Yugoslavia also eventually started permitting people to be released pending trial, International Criminal Tribunal for the former Yugoslavia (as amended 14 March 1994) r 65. The Special Tribunal for Lebanon could theoretically release accused persons, but to date, none of them have been arrested. Rules of Procedure and Evidence, Special Tribunal for Lebanon (29 November 2010) (STL RPE) R. 102. McDermott, supra note 4, pp. 42-44; Caroline L. Davidson, 'No Shortcuts on Human Rights: Bail and the International Criminal Trial' 60(1) American U. Law Rev. (2010) 7.

${ }^{25}$ Rome statute Article 58(1) 
accused to be released under specific, exceptional circumstances. ${ }^{26}$ By stating that accused persons must be released unless certain conditions are present supports the non-procedural presumption of innocence by not subjecting accused persons to detention, which is similar to the punishments afforded those who are convicted, unless necessary.

The non-procedural aspect of the presumption of innocence is the part of this right which has been developed the most by the International Criminal Court's case law. The various Chambers have gone beyond a narrow reading of Article 66's text and have strengthened the presumption of innocence to extend beyond the courtroom and Trial Phase. This has allowed the Court to have a presumption of innocence that is in line with international human rights standards, provides good protection for those who are suspected and accused, and strengthens the legitimacy of the Court by showing that the outcomes of each case are not foregone conclusions.

\section{Waiver of the Presumption of Innocence}

Interestingly, through case law, the International Criminal Court has also developed an ability for the accused to waive the right to the presumption of innocence. Not provided for in the Rome Statute or other Court documents, waiver was created during the al Madhi case. ${ }^{27}$ The presumption of innocence can be waived by allowing an entry of a guilty plea. Practically speaking, a guilty

\footnotetext{
${ }^{26}$ Coleman, supra note 3, p. 139; ICC, Prosecutor v. Bemba, ICC-01/05-01/08, Pre-Trial Ch II, Decision on the Interim Release of Jean-Pierre Bemba Gombo and Convening Hearings with the Kingdom of Belgium, the Republic of Portugal, the Republic of France, the Federal Republic of Germany, the Italian Republic, and the Republic of South Africa, 14 August 2009, para. 77 (stating that the decision on release is 'not of a discretionary nature' when all the conditions are met).

${ }^{27}$ ICC, Prosecutor v. al Mahdi, ICC-01/12-01/15, Trial Chamber VIII, Judgment and Sentence, 27 September 2016.
} 
plea is a request on the part of the accused for the factfinder to enter a finding of guilt against them. This bypasses the standard of proof. The accused is stating that the prosecutor has enough proof to meet the standard of proof and that rather than proceeding with the trial process the factfinder should consider the standard of proof met by the prosecutor. Once a guilty plea is accepted the accused is considered guilty, just as they would at the end of a trial that results in a guilty verdict. Thus, both the procedural and non-procedural aspects of the presumption of innocence are waived.

\section{Violations of the Presumption of Innocence?}

From examining the Statute, Rules and case law, the presumption of innocence has developed into a much more protective right than discussed during the drafting of the Rome Statute. It is interesting to note however, that most of the development has occurred during decisions that were not solely focused on the presumption of innocence itself. For example, the main issue in Decision 5 from Ruto and Sang was to specifically develop the No Case to Answer Motion. The presumption of innocence is hardly mentioned or discussed in the decision, although the decision greatly impacts the presumption of innocence's development before the Court. There have however, been a few decisions that have directly dealt with the presumption of innocence, and these are centered on the non-procedural issue of public statements of guilt. While the Court has, to date, not found a violation of the presumption of innocence, these cases are examples of some close calls.

The first example can be found within the Lubanga case. An employee from the Complementarity and Cooperation Division of the Prosecutor's office stated, during a press interview, that 'Mr 
Lubanga is going away for a very long time' ${ }^{28}$ Pre-Trial Chamber I held that this statement did not violate the presumption of innocence. However, the Chamber also stated that the statement was prejudicial to the accused and 'tend(s) to prejudice the public's understanding of the trial' and 'bring(s) the Court into disrepute' ${ }^{29}$ This is because, were the public to believe this statement, they could mistakenly believe that the Court had already decided that Lubanga was guilty or that the Court was guaranteeing that Lubanga would be found guilty and receive a long prison sentence. This dissonance between the potential beliefs of the public and the ongoing nature of the court proceedings, could ultimately call into question the legitimacy and fairness of the Court itself.

During the Libya Situation, the Prosecutor called Saif Gaddafi a 'liar' while being interviewed by Phillipe Sands in Vanity Fair magazine. ${ }^{30}$ This statement was made while reviewing statements made by Gaddafi regarding his knowledge of, and involvement in, the alleged incidents which led to his indictment. ${ }^{31}$ The Pre-Trial Chamber held that while the statement was 'inappropriate in light of the presumption of innocence' no violation occurred. ${ }^{32}$ Their determination that the presumption of innocence was not violated was based on the idea that this statement did not show that the Prosecutor was biased or that he could not carry out his duties. ${ }^{33}$ Their concern regarding this statement centred on the idea that because the Prosecutor is an elected official of the Court, the statements could be seen as the opinion of the Court as a whole. This in turn, could call into

\footnotetext{
${ }^{28}$ ICC, Prosecutor v. Lubanga, ICC-01/04-01/06, Trial Chamber I, Decision on the Press Interview with Ms Le Fraper du Hellen, 12 May 2010.

${ }^{29}$ Ibid.

${ }^{30}$ Philippe Sands, 'The Accomplice', Vanity Fair, 22 August 2011.

${ }^{31}$ Ibid.

${ }^{32}$ ICC, Prosecutor v. Gaddafi, ICC-01/11-01/11, Appeals Chamber, Decision on the Request for Disqualification of the Prosecutor, 12 June 2012, para. 33.

${ }^{33}$ Ibid., para. 35.
} 
question the legitimacy and impartiality of the Court with respect to an accused person during an ongoing case.

In a press release during the Mbarushimana case, the Prosecutor stated that Calixte Mbarushimana was the leader of Forces démocratiques pour la liberation du Rwanda and that members of that group committed more than three hundred rapes while the group was under his leadership. ${ }^{34}$ Rather than making a clear statement that Mbarushimana was guilty of the alleged crimes, the Prosecutor implied that all of the elements of rape as a crime against humanity were committed by the accused. That is, by connecting Mbarushimana's leadership to the crimes against humanity committed by those persons ostensibly under his control, the Prosecutor essentially stated that Calixte Mbarushimana was guilty of the crimes that he was accused of before the Court. Nevertheless, Pre-Trial Chamber I held that there was no violation of the presumption of innocence and chose to ascribe a possible innocuous meaning to the statement by looking at the greater context in which the statement was made. In doing so, the Chamber stated that it would have been 'desirable' for the Prosecutor to phrase his statements in terms of allegations rather than facts because the case was ongoing and no conviction had been determined. ${ }^{35}$ By not using terms such as 'there are reasonable grounds to believe' or 'allegedly' the statement gives the impression that certain facts, and possibly the ultimate decision, had already been proven before the Court. ${ }^{36}$

Additionally, within the same press release the Prosecutor referred to Mbarushimana as a 'genocidaire'. The Court also examined this statement in light of the context and determined the

\footnotetext{
${ }^{34}$ ICC, Prosecutor v. Mbarushimana, ICC-01/04-01/10-51, Pre-Trial Chamber I, Decisions on Defence Request for an Order to Preserve the Impartiality of the Proceedings, 31 January 2011, para. 12.

${ }^{35}$ Ibid., para. 17.

${ }^{36} \mathrm{Ibid}$.
} 
assertion to be 'the result of an oversight, rather than an intended statement' $\cdot{ }^{37}$ With respect to this issue, Mbarushimana was not charged with genocide, and thus this comment was not sufficiently linked to the charges alleged in order to constitute a violation of the presumption of innocence. Therefore, the Court did not find that the presumption of innocence had been violated.

All three of these examples demonstrate that the Court has been grappling with the presumption of innocence and trying to determine where its limits lie. While none of the cases resulted in the Court finding a violation of the presumption of innocence, in each instance the decision admonished the Prosecutor's Office for its behaviour and provided instruction on what should be done differently in the future. Further, in each instance the Court expressed concern for how these kinds of statements could impact the legitimacy and impartiality of the Court, as a whole, in the eyes of the public and international community. This continued focus on the Court's reputation during assessments of whether the presumption of innocence has been violated is interesting because, while respecting the presumption of innocence can be an indicator of whether a court is fair, that is not its main aim. Generally, because the presumption of innocence is a human right, damage to the accused's reputation is the focus when it comes to arguments about whether the presumption of innocence has been violated through a public statement of guilt.

In light of the fact that none of these statements resulted in the Court finding that a violation of the presumption of innocence occurred, it is difficult to imagine what kind of statement would violate the non-procedural aspect of the presumption of innocence as a public statement of guilt. All three statements were made by the Prosecutor himself or by a member of his office. All three statements

${ }^{37}$ Ibid. 
also indicate some level of prejudgment on the part of the Prosecutor's Office. One explanation could be that courts in general are unlikely to find a violation the presumption of innocence based of a public statement of guilt. In other jurisdictions, such as the European Court of Human Rights, the public statement of guilt must be very closely tied to the criminal matter, that is, it must state that the accused is guilty of the alleged crimes in no uncertain terms. ${ }^{38}$ It is arguable that these statements before the International Criminal Court are not expressly related to the crimes that were charged and therefore do not expressly state that the accused guilty.

\section{What remedy fits a violation of the presumption of innocence?}

Although the International Criminal Court has not found, to date, a violation of the presumption of innocence in any of the cases or situations before it, this does not mean that a violation could not be found in the future. It is clear that the International Criminal Court is developing the presumption of innocence into a strong right that can provide protection for people those who are suspected or accused. The near violations discussed in the previous section show that the Court is trying to ensure that the presumption of innocence develops into a meaningful right with defined limits. Without a violation to use as an example, an open question remains: what happens when there is a violation of the presumption of innocence at the International Criminal Court? What would be an appropriate remedy?

\footnotetext{
${ }^{38}$ For an example of a statement that does violate the presumption of innocence see ECHR, Allenet de Ribemont v. France, Series A no 308, 1995 para. 10 where the police said that the accused was an 'instigator' of the alleged crimes. On the other hand, see ECHR, Krause v. Switzerland, 13 DR 73, 1979, where no violation was found when the Swiss Chancellor said the applicant 'committed common law explosive offences and that she must accept responsibility for it'.
} 
The Rome Statute and Rules of Procedure and Evidence are silent on what remedy an accused person could expect if the presumption of innocence were violated. This is not surprising as the Statute and Rules are silent on the issue remedy for the other defence rights as well. As with so many human rights documents, the documents of the International Criminal Court are written so as to state what the law and rules of the Court are, rather than set out what happens if the they are not followed. Instead, the case law at the International Criminal Court has developed the presumption of innocence beyond what is strictly included in the Statute. However, as the case law develops when issues arise, rather than prospectively, the case law too is silent on remedy for potential violations.

In determining what remedy would be appropriate for violations of the presumption of innocence, the International Criminal Court could take four different approaches. The first approach is that the same remedy could be applied to every violation that occurs. Alternatively, the Court could assign one remedy to violations of the procedural aspect and another remedy to violations of the non-procedural aspect. The third approach is that the remedy could depend on the purpose behind the presumption of innocence and how that purpose is affected by the violation. Finally, the Court could determine a remedy on a case-by-case basis depending on what the violation is and the particular case at hand. Ultimately, the International Criminal Court would probably assign the same remedy to all violations of the presumption of innocence. This is because violations rarely occur, any violation's impact would be extremely detrimental to the particular case in which the violation occurred, it would reflect badly upon the Court as a whole and, as is explained below, there is only one appropriate remedy for violations of the presumption of innocence. 
Given that the purpose of the presumption of innocence is to prevent those who have not been convicted of a crime from being treated in the same manner as those who have been convicted, then the remedy should correct violations that hinder this purpose. In that case, the only appropriate remedy is dismissal or discontinuation of the charges against the accused. This remedy would cover both violations of the procedural and non-procedural presumption of innocence and guarantees that the broader structural issues are protected as well. As the International Criminal Court has demonstrated, and as is supported by other courts as well, the presumption of innocence is difficult to violate. When it is violated, it is an extreme instance, which requires a serious, if somewhat extreme remedy.

With violations to the procedural aspect of the presumption of innocence, dismissal of the charges is the only remedy that could adequately correct the violation. This is because the procedural presumption of innocence is directly concerned with the structure of the trial proceedings themselves. A violation to the procedural aspect means that either: the burden of proof has shifted away from the Prosecutor, the standard of proof has lowered, or the factfinder has found a guilty verdict without the burden or standard of proof being met. These are the very necessary standards that keep the rule of law upheld and create the mechanism for a just court. If one of those parts of the presumption of innocence were violated it would call any resulting verdict in the case into doubt. This would potentially allow for innocent people to be convicted and would cause the Court to lose legitimacy. Thus, if there is a violation of any part of the procedural aspect of the presumption of innocence, then the only appropriate remedy would be a dismissal of the charges against the accused. 
A dismissal is also the only appropriate remedy for a violation of the non-procedural aspect of the presumption of innocence. The non-procedural aspect helps to prevent people from being punished without a conviction. If non-convicted individuals were able to experience the same treatment as convicted individuals without going through the trial and conviction process, then there would be no need to have trials at all. Time and money could be saved by not doing adequate investigation, not having trial and still punishing people for their alleged crimes. This is exactly what is prevented by the non-procedural presumption of innocence. Therefore, if individuals are being treated as if they have a conviction without a conviction being entered against them, then the charges against them must be dismissed. To do otherwise would allow for punishment without due process and make the presumption of innocence meaningless.

Some jurisdictions have other remedies for violations of rights that are connected to the presumption of innocence. For example, in common law jurisdictions exclusion of the violative evidence can be sufficient to remedy the issue..$^{39}$ Exclusion of the violative evidence however, would be an insufficient remedy for violations of the presumption of innocence at the International Criminal Court. First, this would not satisfy the structure of the Court's proceedings. Created as a mix of inquisitorial and accusatorial systems, exclusion does not fit into the inquisitorial traits at the International Criminal Court. Secondly, the violative behaviour may not be evidence, and yet may have a significant impact on the case against the accused. This is particularly true with violations of the non-procedural aspect including public statements of guilt. If a public official not

\footnotetext{
${ }^{39}$ For example, in the United States a statement by the accused that violates the accused's right to silence would be excluded from the proceedings. However, the right to silence is not considered a part of the presumption of innocence in that system. See United States Supreme Court, Miranda v. Arizona 384 US 436 (1966).
} 
associated with the Court, someone from the United Nations for example, were to make a public statement of guilt about an accused person, that statement would not be evidence that the accused is guilty and cannot be used as evidence in court. However, that statement could influence the opinion of the factfinder and public and could have a negative impact on the reputation of the accused and the Court itself. Therefore, excluding the statement from the evidence against the accused would not have a bearing on the evidence involved in the case, but the statement would still have a negative influence on the accused and the Court. Consequently, if exclusion were the available remedy, then the remedy would not be effective in such a case and that kind of violation could occur without recourse to the accused.

Another possible remedy for a violation of the non-procedural aspect could be disqualification of the individual who violated the presumption of innocence. This, however, has several potential problems. One is that, like the example given for exclusion of evidence, someone who is not directly involved in the trial could violate the non-procedural presumption of innocence. For example, it is not clear how excluding a person in the Complementarity and Cooperation Division of the Prosecutor's Office, in a similar situation to the Lubanga decision discussed above, would be a remedy should their statement be held to be a violation. In which case, the exclusion of that person would not remedy the situation. Another issue is that in considering the public statements of guilt decisions that have been heard, many were made by the Prosecutor themself. If a statement such as was made in Mbarushimana were to be held to be a violation of the presumption of innocence in a future case, would the Prosecutor or the Prosecutor's Office be disqualified as a remedy? Either way, there is no structure for who would continue with the prosecution of the case. Further, in any of these cases the individual damage to the particular accused person would not be 
remedied and there would be continued questions about the legitimacy and impartiality of the Court.

Thus, the only remedy that is appropriate for a violation of the presumption of innocence is a dismissal of the charges. This holds true for both violations of the procedural and non-procedural aspects. Dismissal is the only remedy that both redresses the wrong that the accused person has suffered and prevents the legitimacy and impartiality of the Court from being damaged. While it may seem an extreme remedy, a violation of the presumption of innocence is not easily found and may itself be considered an extreme circumstance.

\section{Conclusion}

Although the presumption of innocence was not a subject of much discussion during the negotiations of the Rome Statute, its inclusion in the structure of the International Criminal Court was never in doubt. It was included in every draft and incorporated as Article 66 of the Rome Statute. Since the drafting however, the presumption of innocence has been under consideration by the Court many times in the past twenty years. This interpretation has allowed the presumption of innocence to develop beyond the literal reading of Article 66 into a full human right that is in line with international standards.

The development of the presumption of innocence at the International Criminal Court has created clear procedural and non-procedural aspects. The procedural aspect is a mandatory rebuttable 
presumption of law with a clear burden of proof on the prosecutor and a strict standard of proof of beyond reasonable doubt. In addition to the text of Article 66 this aspect has been strengthened by the finding of the defence's right to silence and the invention of no case to answer motions. The non-procedural aspect extends the presumption of innocence beyond the trial context and protects accused and suspected people from being treated as if they are guilty without first being convicted. The Court has upheld this aspect in its decisions respecting in dubio pro reo at pre-trial proceedings, preventing public statements of guilt and preventing too much negative publicity.

Through this development the Court has shown that it is taking the presumption of innocence seriously. To date, however, no violation of the presumption of innocence has been found in any of the cases before the International Criminal Court. Because violations have not been found there are some questions as to how much the presumption of innocence can be infringed upon before a violation occurs and there are further questions about what will happen once that violation is found. It is important that the Court keeps developing the presumption of innocence, not only to keep the right in line with international human rights, but also because a remedy will need to be provided once a violation occurs. Considering the importance of the presumption of innocence to both the structure of the proceedings and rule of law and to the accused's particular case, the only remedy that could be developed is a dismissal of the charges against the accused.

As the Court has demonstrated in its case law so far, courts rarely hold that the presumption of innocence has been violated. This is in part because a violation of the presumption of innocence is a very serious issue that can call into question the reputation and impartiality of the court itself. The Court has not yet found a violation of the presumption of innocence but that does not mean 
that a violation is not possible in future cases. While the International Criminal Court has made great strides in interpreting the presumption of innocence so that it has developed into a full human right, until violations are found the limits of how far that right may be infringed upon might not be determined. Meanwhile, the question of what remedy will be appropriate when a violation occurs remains open. While dismissal is the only meaningful remedy that upholds both the presumption of innocence and its purpose, it might also seem extreme in light of the gravity of the cases before the International Criminal Court. Nevertheless, it is probably the remedy that will develop should a violation of the presumption of innocence be found in a future case before the International Criminal Court. 